\title{
Techno-economic performance of mechanised fishing in Karwar, Karnataka
}

\author{
N. ASWATHY, R. NARAYANKUMAR, N. K. HARSHAN AND C. ULVEKAR* \\ ICAR-Central Marine Fisheries Research Institute, Kochi -682 018, Kerala, India \\ "Karwar Research Centre of ICAR-Central Marine Fisheries Research Institute, Karwar - 581 301, Karnataka, India \\ e-mail: aswathy.icar@gmail.com
}

\begin{abstract}
The techno-economic and financial performance of mechanised purse seiners and trawlers operating in Karwar Fishing Harbour was compared using various indicators. The average diesel consumption per trip was 1791 for purse seiners and 791 for trawlers. The average operating cost and gross revenue per trip were ₹ 21,818 and ₹44,383 respectively for purse seiners and ₹4,803 and ₹6,571 respectively for trawlers. Oilsardines and mackerels contributed more than $85 \%$ of the catch of purse seiners whereas shrimps and flatfishes contributed nearly $50 \%$ of the catch of trawlers. Capital productivity was higher (operating ratio - 0.49) for purse seiners than trawlers (operating ratio - 0.73). The economic and financial performance indicators like net benefit-earnings ratio (0.43), benefit-cost (BC) ratio (1.75) and internal rate of return, IRR $(117 \%)$ were higher for purse seiners which suggested that the investment on purse seiners is a more viable undertaking when compared to trawlers in the location.
\end{abstract}

Keywords: Economic performance, Internal rate of return, Net-benefit earnings ratio, Operating ratio

\section{Introduction}

Mechanisation of fishing was initiated in Karnataka during 1957-58 (Pattanayak, 1988). Uttarkannada, Udupi and Dakshin Kannada are the three important maritime districts in the state. While multiday fishing is undertaken in Dakshin Kannada (Manglaore Fishing Harbour) and Udupi districts (Malpe Harbour), only single day fishing is undertaken by the fishermen in Uttar Kannada District (Karwar Harbour). Karnataka coast is traditionally known as the "mackerel coast" and purse seiners contribute a significant share of mackerel and oilsardine landings in the state (Mohamed et al., 1998). The number of purse seiners in Karnataka increased from 300 in 1980 to 422 in 2010 (Dhulkhed and Bhatt,1985; Kurup et al., 1987; DAHDF and CMFRI, 2012). In the early eighties, purse seiners were the dominant fishing gear contributing more than $50 \%$ of the catch in the state whereas its share declined in the nineties to $45 \%$ (Kurup et al., 1987). The purse seine catch increased from an average 97,586 $\mathrm{t}$ in the $80 \mathrm{~s}$ to 1,05,097 $\mathrm{t}$ in 2011 (Mohamed et al., 1998; CMFRI, 2012)

Commercial purse seining started in India in the 1970s. Karnataka fishermen were the first to initiate purse seining in India by shifting from rampani nets (Shahul Hameed and Mukundan, 1991). Purse seining has improved over the years with increase in the volume of nets, increase in engine horse power and multiday fishing (Mohamed et al., 1998). Karwar Fishing Harbour is located in Uttarkannada District of Karnataka and 47\% of the marine fisherfolk and $44 \%$ of fishing units in the state operate in this district. Majority of the mechanised purse seiners in Uttarkannda district operate from Karwar Fishing Harbour.

Profitability of fishing operations are affected by fluctuations in quantities, composition of fish catch, changes in fish prices, prices of key inputs and changes in consumer demand. Information on economic performance of fishing units provides guidance to investors and bankers for arriving at credit and investment decisions. It will also support the government for designing and implementation of policies on incentives/subsidies to fishing sector and sustainable fisheries management. This study focused on the economic performance of mechanised fishing units operated from Karwar Fishing Harbour to identify the types of fishing units which are economically more viable. Profitability of fishing operations was assessed using different economic and financial indicators.

\section{Materials and methods}

The data were collected by weekly observations from the trawlers and purse seiners using random sampling method during the year 2011. Fixed and operational expenses and revenue details of purse seiners and trawlers collected from Karwar Fishing Harbour during the year 2011 was used for the study. Expenses on fuel, lubricant oil, food, bata, crew share, auction charges as well as cost involved in repair and maintenance of fishing crafts and gears were included under operational costs. Since all the fishermen received diesel at VAT exempted rates, these 
subsidised rates were used for calculating the diesel cost. Depreciation and interest on fixed capital were included under annual fixed cost. Depreciation was calculated by straight line method based on the expected life of craft, gears, engines and other accessories.

Previous studies on the economic performance of fishing units employed different indicators like net -benefit earnings ratio, rate of return (LeRy et al., 1999; Tietze et al., 2001), net returns (Panikkar et al., 1994; Kasim et al., 2013), capital productivity and labour productivity (Narayanakumar et al., 2009; Aswathy et al., 2011). In this study various indicators like operating ratio, net benefit-earnings ratio, internal rate of return (IRR) and benefit-cost ratio (BCR) were used to analyse the economic and financial performance of purse seiners operated in Karwar Harbour.

Net profit $=$ Gross earnings - All costs (fixed and operational expenses).

Operating ratio $=$ Operating costs $/$ Gross earnings

Net cash flow/Total earnings (TE) ratio is the ratio of net profit to total earnings expressed as a percentage. A value of more than 10 can be considered as good (LeRy et al., 1999, Tietze et al., 2001).

The financial performance was assessed using BCR and IRR:

$\left.\mathrm{BCR}=\left\{\sum_{\mathrm{i}} \mathrm{B}_{\mathrm{i}} /(1+\mathrm{r})^{\mathrm{i}}\right\} /\left\{\sum_{\mathrm{i}} \mathrm{C}_{\mathrm{i}} / 1+\mathrm{r}\right)^{\mathrm{i}}\right\}$

where, $\mathrm{B}_{\mathrm{i}}=$ total revenue earned at year $\mathrm{I} ; \mathrm{C}_{\mathrm{i}}=$ total costs at year $\mathrm{i} ; \mathrm{i}=$ average number of years of operation of fishing units; $r=$ discount rate

IRR of an investment is the discount rate at which the net present value of costs equals the net present value of benefits of the investment.

$\left.\mathrm{NPV}=\sum_{\mathrm{i}} \mathrm{B}_{\mathrm{i}} /(1+\mathrm{r})^{\mathrm{i}}-\sum_{\mathrm{i}} \mathrm{C}_{\mathrm{i}} / 1+\mathrm{r}\right)^{\mathrm{i}}=0$

where, NPV = net present value; $r=$ internal rate of return; BCR and IRR were worked out for a 10 year investment period assuming $5 \%$ yearly increase in operating costs and revenues.

\section{Results and discussion}

Purse seiners operated from Karwar had an overall length of 45-50 ft with engine capacities varying from 104-140 HP. The fishing voyage usually started at $08.00 \mathrm{hrs}$ and ended by $1900-2000 \mathrm{hrs}$ and the fishing time varied depending on the catch. The fishing grounds were near Karoli, Bhatkal and Goa up to $40 \mathrm{~m}$ depth at a distance of $15 \mathrm{~nm}$. The fuel requirement was $30 \mathrm{l} \mathrm{h}^{-1}$ and the average fuel consumed by a purse seine unit was 1791 per trip (Table 1). The Government of Karnataka provided
VAT exempted diesel through fishermen societies. Diesel was supplied based on the capacity of the engine and the maximum quantity given was $35 \mathrm{kl}$ per boat per year. Fishermen cooperative owned diesel bunks supplied VAT exempted diesel to the fishermen in the harbour. Purse seiners on an average undertook 240 fishing trips in a year. Purse seiners did not carry ice onboard as the catch mainly consisted of oilsardine which was mainly sold to fishmeal plants.

Trawlers operated from Karwar Harbour were 32 - $36 \mathrm{ft}$ boats with an engine capacity of 40-90 HP. Single day trawlers in Karwar were more than 10 year old wooden boats and average crew size was 5 members (Table 1). Usual fishing was at $36 \mathrm{~m}$ depth and the main fishing season consisted of 8 months only in a year i.e. during December - May and August and September. The duration of usual fishing trip was $12 \mathrm{~h}$ and majority of the boats departed by $0400 \mathrm{hrs}$ and landed at $1600 \mathrm{hrs}$. The main catch of trawlers consisted of shrimps, flatfishes, silverbellies, crabs and croakers. Majority of the trawl boats in the harbour bring trash fishes consisting of stomatopods and other low value fishes which are generally taken by the fish meal plants in Karnataka. Nearly $30 \%$ of the gross revenue was given as wages for the trawl workers. All the fishing units used subsidised diesel supplied through the cooperative societies.

Table 1. General particulars of mechanised fishing units in Karwar

\begin{tabular}{lll}
\hline Particulars & Purse seiners & Trawlers \\
\hline OAL (Feet) & 46 & $32-36$ \\
Engine power (HP) & $104-140$ & $48-60$ \\
Crew size (No.) & 28 & 5 \\
Fuel consumption $\left(1\right.$ trip $\left.^{-1}\right)$ & 179 & 79 \\
Catch $\left(\mathrm{kg} \mathrm{trip}^{-1}\right.$ boat $\left.^{-1}\right)$ & $3000-4000$ & 202 \\
\hline
\end{tabular}

\section{Costs and revenue of fishing}

Purse seiners operated from Karwar Fishing Harbour were 5-10 year old boats. The present values of the boats were taken for calculating the fixed investment. The average cost of hull was ₹25 lakhs and that of engine was ₹5 lakhs. The cost of purse seine net was ₹10 lakhs. All the boats used echo-sounders, GPS and wireless sets. The average investment cost was ₹48 lakhs for purse seiners and ₹8.7 lakhs for trawlers. Annual fixed cost was worked out at $15 \%$ interest rate and expected life of 10 years for hull and 5 years for engine and gears.

Average catch per boat was $3.4 \mathrm{t}$ per fishing trip for purse seiners and $202 \mathrm{~kg}$ for trawlers. Fishes were sold in nearby fish markets in Karwar as well as transported to Udupi, Mangalore, Goa and northern districts of 
Kerala. There is a registered co-operative society called Karwar Purse-seine Meenagar Sahakari Sangam which undertook the auctioning and marketing activities of the purse seine boats and kept record of catches and revenue received by the members. The co-operative provided financial assistance to the tune of ₹70,000 per boat per year for day-to-day activities of the boats based on the repayment performance in previous years. The traders and commission agents remitted the price fixed for the catch at the society and a part of the amount was paid directly to the boat owners. Six percent of the value of catch was charged as commission by the society and $4 \%$ of which was returned back at the end of every year to the owners. Five auctioneers and 20 traders were involved in trading of purse seine catch in the harbour.

Economic analysis of the purse seine operations in Karwar showed that the average operating cost per trip was ₹1,838 and the gross revenue was ₹44,383. The net profit earned per trip was ₹19,205 (Table 2). Average crew size was 28 per fishing trip. Crew received daily bata, ration and crew share. Crew bata was a fixed amount given to the workers in every fishing trip irrespective of quantity of catch. The crew share was given as percentage of the gross revenue earned per fishing trip. It varied from 30 to $50 \%$ of the gross/net revenue depending on the boat. The revenue was shared between the owner and crew at the rate

Table 2. Average costs and revenues (₹ per fishing trip)

\begin{tabular}{lll}
\hline Particulars & Purse seiners & Trawlers \\
\hline Operating costs & & \\
Fuel & 6762 & 2981 \\
Crew wages & 13315 & 1223 \\
Food and bata & 988 & 300 \\
Ice & - & 51 \\
Auction charges & 548 & 114 \\
Others & 225 & 134 \\
Total operating cost & 21838 & 4803 \\
Gross revenue & 44383 & 6571 \\
Fixed cost & 3340 & 1415 \\
Net profit & 19205 & 353 \\
\hline
\end{tabular}

of 70:30 in cases where operating costs were not deducted from the revenue. Fifty per cent of the net revenue was paid as crew share in some of the boats after deducting operating costs from gross revenue. The total payments to the crew consisted of crew share, food for the crew and crew bata. Crew share and expenses on diesel accounted 61 and $31 \%$ respectively of the total operating costs. Food and bata constituted $4.5 \%$ of the operating cost. Other costs included jetty rent, water charges, auction charges and expenses for repair and maintenance.

Tietze et al. (2001) reported the investment cost of purse seiners of $14.6 \mathrm{~m}$ OAL in Karnataka at US\$66163 and total costs of operation at US\$36067. The net profit
(US\$1376) recorded was higher than the present study at current levels of currency exchange rates. Capital productivity was higher for purse seiners and lower for trawlers in Karwar as compared to the national averages reported by Narayankumar et al. (2009).

In the case of purse seiners, the lowest price realised was for oilsardine Sardinella longiceps (₹7 $\mathrm{kg}^{-1}$ ) and Sardinella fimbrata ( $₹ 10 \mathrm{~kg}^{-1}$ ) and the highest was for black pomfret at ₹ $159 \mathrm{~kg}^{-1}$ and for trawlers the lowest price realised was for squilla at ₹2 $\mathrm{kg}^{-1}$ and lizardfishes (₹14 $\mathrm{kg}^{-1}$ ) and highest for Fenneropenaeus indicus (₹131 kg $\mathrm{kg}^{-1}$ ) and Metapeneaus monoceros (₹82 kg-1) (Table $3 ; 4)$. The price received for many of the fish varieties at Karwar Harbour were lower than that of the prices recorded in nearby coastal states like Kerala, Goa and Maharashtra (CMFRI, 2012; Aswathy et al., 2014).

Table 3. Average catch, value and price realised for resources landed by purse seiners per fishing trip

\begin{tabular}{llll}
\hline Name of fish & Catch $(\mathrm{kg})$ & Value $(₹)$ & Price $\left(₹ \mathrm{~kg}^{-1}\right)$ \\
\hline Oilsardine & 2552 & 17172 & 7 \\
Mackerel & 440 & 14196 & 32 \\
Sardinella fimbriata & 310 & 3198 & 10 \\
Anchovies & 48 & 3228 & 67 \\
Black pomfret & 25 & 3977 & 159 \\
Silverbellies & 24 & 2000 & 83 \\
Others & 64 & 612 & 10 \\
Total & 3463 & 44383 & \\
\hline
\end{tabular}

Table 4. Average catch, value and price realised for resources landed by trawlers per fishing trip

\begin{tabular}{llll}
\hline Name of fish & Catch $(\mathrm{kg})$ & Value $(₹)$ & Price $\left(₹ \mathrm{~kg}^{-1}\right)$ \\
\hline F. indicus & 1 & 170 & 170 \\
M. monoceros & 7 & 532 & 76 \\
M. dobsoni & 34 & 2448 & 72 \\
P. stylifera & 16 & 800 & 50 \\
Flatfish & 18 & 395 & 22 \\
Rays & 6 & 204 & 34 \\
Crabs & 14 & 448 & 32 \\
Lizardfish & 4 & 53 & 13 \\
Silverbellies & 9 & 159 & 18 \\
Croakers & 11 & 275 & 25 \\
Lactarius & 5 & 275 & 55 \\
Ribbonfish & 1 & 37 & 37 \\
Mackerel & 3 & 114 & 38 \\
Pomfrets & 3 & 176 & 59 \\
Threadfin breams & 3 & 79 & 26 \\
Squilla & 48 & 100 & 2 \\
Others & 19 & 306 & 16 \\
Total & 202 & 6571 & \\
\hline
\end{tabular}

\section{Economic and financial performance indicators}

The capital productivity was higher for purse seiners with operating ratio of 0.49 . The high IRR $(117 \%)$ and $\mathrm{BCR}>1$ indicated the financial viability of purse seine investment. For trawlers, the net 
benefit-earnings ratio, B-C ratio and IRR were lower indicating that the investment in trawlers is less viable when compared to purse seiners (Table 5).

Table 5. Economic and financial indicators of trawlers and purse seiners operating from Karwar

\begin{tabular}{lll}
\hline Indicators & Purse seiners & Trawlers \\
\hline Capital productivity (Operating ratio) & 0.49 & 0.73 \\
Labour earnings (₹ labour $^{-1}$ trip $^{-1}$ ) & 511 & 305 \\
Annual net profit $(₹)$ & 46,09200 & 70,600 \\
Net benefit-earnings ratio & 0.43 & 0.05 \\
IRR $(\%)$ & 117 & 43 \\
B-C ratio & 1.75 & 1.17 \\
\hline
\end{tabular}

The economic and financial performance indicators showed that the single day purse seiners in Karwar as a more viable enterprise when compared to trawlers and there is further scope to enhance the revenue earned by the boats and incomes of fisherfolk, considering the sizable quantity of fish caught by the purse seiners in the region. The revenue realised was comparatively less as the catch primarily comprised of oilsardine which had low consumer demand and fetched low price in the state. There was restriction in addition of new boats to the existing fleet and only replacements were allowed in the fishing harbour. Due to the restriction in entry of new boats and low price realised for most of the resources, more number of purse seiners were not added to the fleet in the harbour. Purse seiners showed better economic performance than trawlers in Karwar Fishing Harbour. Though purse seiners harvested good catch, the price realised was less and bumper catches often led to deterioration in quality of fish as the boats were not carrying ice onboard. Even though there is very good demand for oilsardine in neighbouring states like Kerala, the high perishability and spoilage loss in transit prevented its large scale transport to neighbouring states. Better revenue to the fishermen could be achieved through adoption of better preservation methods which minimise spoilage losses; through better marketing channels and promotion of inter-state trade. Even though there exists a self-imposed mechanism in the harbour by the fishermen for sustainable fishing through restrictions in addition to existing fleet; capture of large quantities of fish for fish meal purpose will have serious implications on resource sustainability. Hence policy intervention is necessary to ensure long term sustainability of the resources as well as nutritional security of consumers.

\section{Acknowledgements}

The authors are thankful to the Director, ICAR-CMFRI, Kochi for the facilities provided. Thanks are also due to Dr. K. K. Philippose, Scientist-in-Charge,
Karwar Research Centre of ICAR-CMFRI for the support provided during data collection.

\section{References}

Aswathy, N., Shanmugam, T. R. and Sathiadhas, R. 2011. Economic viability of mechanised fishing units and socio-economics of fishing ban in Kerala. Indian J. Fish., 58(2): $115-120$

Aswathy, N., Narayanakumar, R. and Harshan, N. K. 2014. Marketing costs, margins and efficiency of domestic marine fish marketing in Kerala. Indian J. Fish., 61(2): 97-102.

CMFRI 2012. Annual report 2011-12, Central Marine Fisheries Research Institute, Kochi.

DAHDF and CMFRI 2012. Marine fisheries census, 2010 Karnataka, part II 7, 2012. Department of Animal husbandry, Dairying \& Fisheries and Central Marine Fisheries Research Institute, Kochi.

Dhulkhed, M, H. and Bhatt, K. Uma 1985. Purse-seine fishery for oilsardine in the South Karnataka coast and its effects on the indigenous fishery. Indian J. Fish., 32(1): 55-63.

Kasim, H. M., Syda Rao, G., Rajagopalan, M., Vivekanandan, E. Mohanraj, G., Kandasami, D., Muthiah, P., Jagdis, I., Gopakumar, G. and Mohan, S. 2013. Economic performance of artificial reefs deployed along Tamil Nadu coast, South India. Indian J. Fish., 60(1): 1-8.

Kurup, K. N., Nair, K. K., Annam, V. P., Beena, M. R. and Kambadkar, L. 1987. An appraisal of marine fisheries of Karntaka and Goa, Special publication No. 36. Central Marine Fisheries Research Institute, Kochi, 104 pp.

LeryRy, J. M., Pardao, L. J. M and Tietze, U. 1999. Economic viability of marine capture fisheries, Findings of a global study and an interregional workshop, FAO Fisheries Technical Paper No. 377, FAO, Rome, 130 pp.

Mohamed, K. S., Muthiah, C., Zacharia, P. U., Sukumaran, K. K, Rohit, P., Krishanakumar, P. K. Marine fisheries of Karnataka State, India. 1998. Naga, 21: 10-15.

Narayanakumar, R., Sathiadhas, R. and Aswathy, N. 2009 Economic performance of marine fishing methods in India. Mar. Fish. Inf. Serv. T\&E Ser., 200: 3-16.

Panikkar, K. K. P., Sehara, D. B. S. and Kanakkan, A. 1994. An economic evaluation of purseseine fishery along Goa coast, Mar. Fish. Inf. Serv. T\&E Ser., 127: 4-8.

Pattanayak, S. K. 1988. Impact of mechanisation of fisheries development in Karnataka. J. Indian Fish. Ass., 18: 151-154.

Shahul Hameed, M. and Mukundan, M. 1991. Strategies for the development and management of purseseine fishing in 
India. CMFRI Bulletin, National Symposium on Research and Development in Marine Fisheries Sessions V, VI, VII, 44(3): 643-647.
Tietze, U., Prado, J., Le Ry, J. M. and Lasch, R. 2001. Technoeconomic performance of marine capture fisheries. FAO Fisheries Technical Paper, 421, FAO, Rome, 79 pp. 